\title{
Reportage of Decriminalizing LGBTQ \\ Community in India by Supreme Court: Content Study of Indian Newspapers in English Language
}

\author{
Dr. PARTHASARATHI \\ Department of Physics, Maharaja Agrasen College, \\ University of Delhi, Delhi, India \\ E-mail: parthadelhi@gmail.com
}

\section{Grishma KUMARI}

Department of English Journalism, Indian Institute of Mass Communication, Delhi, India

\begin{abstract}
India has been undergoing substantial transformations in the socio-economic, political and cultural realms which have witnessed proliferation of media in all forms. These have been actuated by factors including western education and its associated values which had resulted in the gradual disintegration of the traditional values, norms, and cultural proscriptions. Since the majority opinion in Indian society had always demonstrated a neutral stance on homosexuality, any media reportage related to homosexuals has received neutral coverage in the past. Those sections in the society which subscribe to beliefs that homosexuality is not part of the Indian culture too have found space in reporting in print media resulting in a 'diplomatic' coverage of homosexuality in India. This paper is instituted to provide in-depth insight into the representation of homosexuality in print media namely the national dailies for a one-week period after the Supreme Court Verdict on decriminalization of homosexuality in India. Employing content analysis of national dailies and using a combination of quantitative and qualitative methods, this study aims to analyze the agenda setting by the media and how it portrayed homosexuality and homosexuals post the verdict of the Supreme Court.
\end{abstract}

Keywords: Article377 of IPC; LGBTQ; Agenda setting; Supreme Court verdict; Content analysis. 


\section{Introduction}

The reference of homosexuality finds mention in pre-colonial societies in India. Homosexuality was treated as heinous offence in Manusmriti (Bühler, 1886) and punishment for such offence was prescribed. In Islamic period, the Muslim Shariat law (Abdulla et al., 2018) treats homosexual conduct as a serious offence. Therefore, all major religions practiced in India are critical about homosexuality and considers it as a serious digression.

British period saw codification of laws and the first enactment took place for uniform criminal laws in India in 1860. Under the Indian Penal Code (IPC) (Law Commission of India, 1971), uniform prescription of homosexual behavior in the form of unnatural offences its nature and punishment was prescribed. Although sexual minorities have remained in existence in Indian society in numerous forms such as kinners or hijra (Lewis, 1990) and other nondescript silent minority, their issues have never seriously been articulated as these issues were confined to certain specific strata of society. Beginning of 19th century saw various civil society organizations (Sen Gupta, 2005) in India actively articulating the rights of LGBTQ (Lesbian, Gay, Bisexual, Transgender, and Queer) minorities. Various magazines like Bombay Dost (Humsafar Trust, n.d.) highlighted the plight of lesbian, gay and bisexuals in public forum in the late 1980's. Certain organizations like Sakhi (Dave, 2010), a lesbian collective in Delhi played pivotal role in furthering LGBTQ minority movement in India.

The late 20th century witnessed a gradual buildup of gay/ lesbian/ bisexual/ transgender movement worldwide which brought to the fore the rights of those discriminated against because of their sexuality. This was reflected in the declaration of US Human Rights Committee in mid-1990's which held that the anti sodomy law of Tasmania (Croome, n.d.) violated the right to privacy and the right to non-discrimination guaranteed to all persons under the International Covenant on Civil and Political Rights (General Assembly Resolution, 1966). In Scandinavia too, the provision of equal rights for sexual minorities, including marriage rights, became an important social agenda. The other major development includes the amendment in South African Constitution in 1997 (The Constitution of the Republic of South Africa, 1996) which for the first time expressly prohibited discrimination on grounds of sexual orientation. However, India was yet to witness any such movement which aimed at extending justice to hitherto marginalized communities like LGBTQ.

In fact, most human rights organizations in India including the People's Union of Civil Liberties (PUCL) ${ }^{1}$ did little to address the question of rights of gays,

1 People's Union for Civil Liberties (PUCL) (n.d.). Retrieved from: http://www.pucl.org/. Accessed on November 2019. 
lesbians, bisexuals and trans-genders who were oppressed due to their sexuality. This was mainly due to the fact that any discussion on sexuality, even in liberal and radical circles, was adjudged as frivolous and bourgeois issue. This prevented homosexuality from becoming a matter of priority for the society and projected it as something deviant and unnatural that is at best defended as an individual freedom. This instituted legal discrimination against sexual minorities which operates through the criminal and civil law systems of the land. These regimes of discrimination are often analyzed underneath the subsequent heads:

\section{(a)Prevention of unnatural offences under Indian Penal Code}

Legal Discrimination against the sexual minorities takes many forms, the most notorious being Section $377^{2}$ of the IPC, a British colonial legislation criminalizing homosexual behavior, that continues to be in the Indian statute book although it has long since been removed from the British statute book. This section states that, "Whoever voluntarily has carnal intercourse against the order of nature with any man, woman, or animal, shall be punished with imprisonment of either description for a term which may extend to ten years and also be liable to fine." The unnatural offences under IPC are sodomy or bestiality. The parties involved in this offence active and passive both are liable for punishment as per the above section. Therefore, this section clearly shows that sodomy is prohibited in India.

(b) Right to privacy of minority LGBTQ community

The right to life and personal liberty includes the right to privacy. It was ruled on August 24, 2017 by the Supreme Court that the Right to Privacy is a fundamental right of Indian citizens under the Constitution of India under 'Right to life and personal liberty' enshrined in Article $21^{3}$. This implies that right to privacy is part of the fundamental right guaranteed to every citizen and enforceable by the courts through a set of Writs (Choudhry et al., 2016). Hence, it is the duty of the state to ensure that the same be granted to vulnerable sections like the LGBTQ community. Sadly, the same has not been diligently observed as the LGBTQ community was labeled criminals under IPC prior to the Supreme Court judgment on Section 377 $\mathrm{IPC}^{4}$ decriminalizing homosexuality in India.

This research utilized the theoretical framework of Agenda Setting and its extension, the Framing Theory. McCombs and Shaw (1972) were the first researchers

2 Section 377 in the Indian Penal Code - Indian Kanoon. Retrieved from: https://indiank anoon.org/doc/1836974/. Accessed on November 2019.

3 Article 21 in The Constitution Of India 1949 - Indian Kanoon. Retrieved from: https:// indiankanoon.org/doc/1199182/. Accessed on November 2019.

4 Full text of Supreme Court's verdict on Section 377 on September 6, 2018. Retrieved from: https://www.thehindu.com/news/resources/full-text-of-supreme-courts-verdicton-section-377-on-september-6-2018/article24880713.ece. Accessed on November 2019. 
to coin the term Agenda Setting. Framing theory, described as the second level of Agenda setting, tells us how to process information articulated by the article of media and hence affect the perception of the viewer or the reader (Weaver, 2007). McCombs, Llamas, Lopez-Escobar, Rey (1997) demonstrated that agenda-setting research at the second level deals with the influence of 'attribute' salience, whereas the first level agenda-setting illustrates the influence of 'issue' salience. Balmas and Sheafer (2010) inferred that there is a shift in media's role from telling us "what to think about" at the first level agenda-setting to that of media's function of telling us "how to think about" at the second level agenda-setting. The second level of agenda-setting considers how the agenda of attributes affects public opinion (McCombs \& Evatt, 1995). Furthermore, Ghanem (1997) demonstrated that the certain attributes agendas in the news with low psychological distance drove compelling arguments for the salience of public agenda. The agenda setting role of the news media is a form of hegemony that is evident the world over (David and Pavlik, 2003). Scheufele (2000) propounds that framing and agenda-setting possess distinct theoretical boundaries, operate via distinct cognitive processes, namely accessibility vs. attribution, and relate to different outcomes that leads to perceptions of issue importance or interpretation of news issue. Price and Tewksbury (1997) argues that agenda-setting and framing are built on different theoretical principles: agenda-setting is based on accessibility, while framing is concerned with applicability. This means that the basis of framing theory rests on the fact that the media focuses its attention on certain events and then places them within a field of meaning. Thus, framing involves the process of selecting certain aspects of an issue to bring people's attention and to lead them to a particular line of interpretation (Entman, 1993; Scheufele, 1999).

Studies have been carried out worldwide (Chen, 2018; Yan, 2017; EUAFR, 2009; Sinkhorn, 2011; Schastneva, 2016; Tabangcura, 2011; Jawale, 2016) to ascertain the influence of media on framing the issues pertaining to LGBTQ community. Content analysis was carried out by Njoroge Stanley Mbugua (2010) on the representation of homosexuality in the Kenyan print media, namely the national dailies which included The Daily Nation and The Standard for a five-year period. This study analyzed how the media portrayed homosexuality and homosexuals to its readers and concluded that the media choose to portray homosexuality in a negative manner as this conforms to the general public idea or stereotype images of homosexuality. It lamented that the media did not place more focus on generating unbiased reports. The content analysis carried out by Carson Cook University of Tennessee, Chattanooga (2018) of nine television shows from the 2016-2017 season across broadcast and streaming platforms seeks to understand the representation of lesbian, gay, bisexual, and transgender characters. The study updates a content analysis published by Raley and Lucas (2006) that studied the 
2001 television season. This study aimed to understand how the representation of LGBT characters on television has changed since 2001, how representation of bisexual and transgender characters differs from homosexual characters and how representation on streaming platforms differs from broadcast shows. In this study, the researchers questioned whether or not the inclusion of gay and lesbian characters on television contributes to the reduction of negative stereotypes about gay and lesbian individuals and communities. It concluded that there was evidence of improvement in the image of gay men and lesbian women. Research conducted by Calzo and Ward (2009) concluded that television is a site of achievement and contestation, a site where gays and lesbians once faced exclusion and, more recently, have been represented by stereotypically negative portrayals that have been shown to significantly affect viewers perceptions of homosexuality. According to them, greater media exposure had a slight mainstreaming effect on audiences. Indeed, increased exposure to media may then influence groups with disparate perspectives to have a more similar attitude toward homosexuality. Hart (2000) also concluded that negative portrayals of gay men and lesbian women influence viewers' beliefs about these sexual minority groups. Another study conducted by Holz Ivory, Gibson, and Ivory (2009) researches the gendered homosexual relationships of couples from shows on Primetime television from 2001 to 2004. The results indicate that, much like heterosexual couples, gay and lesbian couples on the television shows are portrayed as gendered. Chen (2018) found out a considerable shift in Time magazine's coverage on the LGBT community during the last decade which was tightly correlated with the reformation of public opinions and social reconstruction. But the study did not clarify on the exact role that news content played in reshaping public stereotypical opinions on issues concerning marriage equality, diversity and inclusiveness of the sexual minority group. The study concluded that public images of the LGBT community have been differently depicted and reformed on the basis of mass media coverage. The study conducted by Sinkhorn (2011) to analyze the use of framing of LGBTQ issues by the selected U.S. newspapers (The New York Times, Wall Street Journal, and USA Today) concluded that they did not use fear appeals in persuasive articles on LGBTQ issues and generally chose to take a neutral stance on LGBTQ issues rather than using the morality frame. Further, it showed that the morality frame did not frequently appear in editorial coverage of the New York Times. However, the Wall Street Journal and USA Today chose to take neutral stances rather than using either frame. The New York Times, which is considered a liberal newspaper, applied the equality frame frequently and took a supportive stance on LGBTQ issues. The Wall Street Journal and USA Today used opposing viewpoints that did not include threats, in order to present a balanced story rather than question or mock validity. The Times only used the opposing viewpoint once in order to take 
a neutral stance on LGBTQ issues, but the same was done in order to question and sometimes mock their validity.

While both the substantive and the affective attributes are important in determining the efficacy of Framing Theory, this study is pressed to determine the latter as a factor in shaping of public opinion on issues pertaining to LGBTQ community in India. In this paper, the selected national newspapers are tested to see the extent of the dominant role played by the Agenda Setting theory and the Framing theory in deciding the articles that were published on homosexuality over the stated period under study.

\section{Objectives of the study}

The present research is carried out with to understand the role played by the media in framing social perceptions on matters, which had hitherto been considered as a taboo in the society. The time changing perceptions of society must be engineered by existing agents in the social milieu, which become dominant at a certain point depending on various socio-political factors prevalent in the society.

Our present efforts are actuated by beliefs, which needed to be verified based on actual data collected. Such beliefs are formulated in the form of research questions, which are stated as:

Research Question 1: Is it possible to break the taboo and the associated stigma that surrounds individuals or a specific minority group in Indian society particularly if it has legal and religious sanction?

Research Question 2: Does media plays a pivotal role in opinion formation in the society that can even pave way for societal acceptance of social groups like LGBTQ, which do not conform to mainstream norms?

The specific objective of this study includes:

a. Determine the framing/ representation of homosexuality in the newspapers analyzed.

b. Examine how Indian newspapers highlighted the importance of court ruling on the issue of homosexuality.

c. Investigate the agenda set by the Indian daily newspapers regarding homosexuality. While both the substantive and the affective attributes are important in determining the effectiveness of Framing Theory, this study is pressed to determine the latter as a factor in shaping of public opinion on issues pertaining to LGBTQ community in India.

d. To find out the changing social paradigm and attitude towards LGBTQ community and its reflections in media reporting. 


\section{Methodology}

The methodology employed in this paper is a content analysis of the daily national English newspapers in India. The media coverage after the verdict of Section 377 by the Supreme Court is explored through a combination of quantitative and qualitative analysis of content. The quantitative method is used to measure the duration and frequency of the news reported and qualitative analysis is used to interpret the viewpoints presented by the news articles. This supports what Smith (2005) suggests that the blend of both quantitative and qualitative analysis should be used. Qualitative analysis deals with forms and antecedent-consequent patterns of form, while quantitative analysis deals with duration and frequency of form. While analyzing the content, it was important to establish and document the basic features and characteristics of the newspaper reporting and the way in which the newspapers represented issues regarding LGBTQ community.

\subsection{Sampling}

The sample of this study comprises 289 newspaper articles on homosexuals and homosexuality covered from $7^{\text {th }}$ September 2018 to $13^{\text {th }}$ September 2018 of six different newspapers namely Economic Times, Hindustan Times, The Hindu, The Indian Express, The Pioneer, The Times of India. These national dailies are selected for the said content analysis because they have a wider geographical circulation, huge readership and have been consistent in publication in the period. All the seven days of the week including Sunday is taken into consideration after the verdict. All types of stories such as news, personal stories, editorials, photographs, cartoons and commentaries are taken into consideration. The selected time frame ( $7^{\text {th }}$ September $2018-13^{\text {th }}$ September 2018) has seen much coverage on homosexuals and homosexuality after the verdict was announced on $6^{\text {th }}$ September 2018. In addition, the research stopped at $13^{\text {th }}$ September because most of the articles are covered and published by the newspapers in the selected time period. The following table (Table 1) depicts the number of newspaper articles published by the selected national dailies in the period of one week after the verdict was delivered.

\subsection{Coding procedure}

Coding entails putting the units of analysis into already constructed categories employed in content analysis. Latent coding method is used for the same. The five basis mechanisms of media representation of homosexuality developed by $\mathrm{Ku}-$ har (2003) are used in the present research. The basis mechanisms are as follows: stereotyping, medicalization, sexualization, secrecy and normalization which are discussed in detail below. Based on the above theoretical framework, the final categorization of the news articles fell into the following broad categories: Name of different newspapers, dates of articles published, type of story, sampled newspaper 
Table 1. Newspaper articles on homosexuals and homosexuality after the verdict published in different newspapers $\left(7^{\text {th }}\right.$ September $2018-13^{\text {th }}$ September 2018)

\begin{tabular}{lcccccccc}
\hline $\begin{array}{c}\text { Name of } \\
\text { the newspaper }\end{array}$ & $\begin{array}{c}\mathbf{7}^{\text {th }} \\
\text { Sep }\end{array}$ & $\begin{array}{c}\mathbf{8}^{\text {th }} \\
\text { Sep }\end{array}$ & $\begin{array}{c}\mathbf{9}^{\text {th }} \\
\text { Sep }\end{array}$ & $\begin{array}{c}\mathbf{1 0}^{\text {th }} \\
\text { Sep }\end{array}$ & $\begin{array}{c}\mathbf{1 1}^{\text {th }} \\
\text { Sep }\end{array}$ & $\begin{array}{c}\mathbf{1 2}^{\text {th }} \\
\text { Sep }\end{array}$ & $\begin{array}{c}\mathbf{1 3}^{\text {th }} \\
\text { Sep }\end{array}$ & Total \\
\hline Economic Times & 24 & 4 & 8 & 2 & 1 & 0 & 0 & 39 \\
Hindustan Times & 34 & 1 & 4 & 3 & 1 & 0 & 0 & 43 \\
The Hindu & 32 & 0 & 5 & 2 & 1 & 0 & 1 & 41 \\
The Indian Express & 57 & 6 & 2 & 1 & 1 & 1 & 0 & 68 \\
The Pioneer & 10 & 2 & 24 & 8 & 0 & 0 & 0 & 44 \\
The Times of India & 58 & 3 & 11 & 1 & 1 & 3 & 0 & 77 \\
\hline Total & $\mathbf{2 1 5}$ & $\mathbf{1 5}$ & $\mathbf{3 8}$ & $\mathbf{1 1}$ & $\mathbf{5}$ & $\mathbf{4}$ & $\mathbf{1}$ & $\mathbf{2 8 9}$ \\
\hline
\end{tabular}

articles, placement of story, size of the articles, types of headline used, placement of headlines, viewpoints, use of frame on homosexuality, stance on homosexuality, standpoint/treatment of story, qualitative framework of articles, number of photos used, photo category and threats portrayed in opposing viewpoints.

\subsection{Units of analysis}

According to Stacks and Hocking (1998), unit of analysis is what the researcher actually counts and assigns categories, adding the area of social life on which research question focuses. The units of analysis for this study are the sampled articles which are classified in the following heads:

a. Type of story: The articles are classified based on news, personal stories, editorials, photographs, cartoons and commentaries that covered the Supreme Court verdict.

b. Placement of articles: This is where an article is placed in the newspaper, which is categorized as front page, city page, politics page, nation page, editorial page, business page and others.

c. Size of articles: This is the amount of space given to an item. This is categorized in number of words per article that ranged from 0-100,100-500, 500-1000 and 1000 above.

d. Viewpoints: This is considered as the themes of the articles. Themes are coded based on what Kuhar (2003) developed in his study, the five basis mechanisms of media representation of homosexuality: stereotyping, sexualization, secrecy and normalization medicalization and others.

Stereotyping means labelling individuals and making them look not wanted in the community in which they live; Stereotyping primarily relies on rigid gender schemas exploited by the media to present gays as effeminate and lesbians as masculine, drawing on the analogy with their social roles which thus appear as natural rather than socially constructed. 
Medicalization It is a sociological concept explaining how medicine can be applied to behaviors that are not self-evidently medical or biological. It was used to indicate that homosexuals need more medical examination to ascertain their problem. Medicalization of homosexuality is a continuation of the psychiatric discourse on same-sex orientation from the end of the 19th century. In media representations it is manifested as a search for the causes of homosexuality and the consigning of homosexuality to the medical and psychiatric spheres (homosexuality as a disease or a disorder)

Sexualization refers to reversion of one's sexuality. Sexualization is manifested as a reduction of homosexuality solely to sexuality and sex

Secrecy means confidentiality in the practice of homosexuality. The veil of secrecy implied by media representations makes homosexuality appear as something concealed and related to shame and regret.

Normalization means the perception of homosexual have in homosexuality as something ordinary. Media representations of normal homosexuality are representations tailored to the perception of heterosexuals in such a way that they do not threaten their world. Homosexuality is acceptable only when depoliticized.

e. Use of frame on homosexuality: The portrayal of homosexuality is classified into three categories namely negative, positive and neutral. Any news item that contained any of the attributes, relationships, terms, expressions and phrases which have a positive image of the verdict and are in favor, is coded as positive. When a news article or an editorial contained any of the attributes, relationships, terms, expressions and phrases portraying a negative image of the verdict and are against it is coded as negative. When a news article or an editorial is neither positive nor negative towards the verdict, it is as coded neutral. In other words, the content of the news articles in this category shows a balance of both positive and negative arguments.

f. Standpoint/Treatment of story: The standpoints of the newspaper articles are categorized based on five different themes that are apparent: religion and homosexuality, homosexuality and rule of law, homosexuality leads and social stigma, homosexuality as a western influence, homosexuality and discrimination at workplace and others.

g. Qualitative framework of article: This research employs the following framework to help assess stories and classifies whether it is a constructive story, incomplete, negative or fell in the other category.

Constructive stories: These stories are further classified into other categories which characterize stories as constructive if they highlighted the voices of LGBTQ people, or conspicuously has fairness in approach to their issues without any open prejudice, ridicule, or moralizing. Further, the article is deemed to be constructive if it provided research, history and context to the issues of LGBTQ 
community. In addition, weightage is accorded to those articles which used inclusive language to refer to LGBTQ people. If any story did not fall into these categories but has constructive attributes, the category of others is also mentioned. Any story which accounts as incomplete or negative is considered in the 'not applicable' category.

Incomplete stories: The stories that are incomplete are the ones which explicitly lacks voice of LGBTQ people or which fails to address stereotypes in their approach. The failure to address the tendency for biased coverage or provide context, which lacks adequate context or are written without appropriate research \& history context and lack of inclusive language qualifies to be fit as incomplete stories. Any such incomplete story which did not find any place in this is classified as others. The story which accounted to be constructive and negative is considered as 'not applicable'.

Negative stories: The stories which are viewed as negative are done on the basis that lacks voice of LGBTQ people, which perpetuates stereotype or has a biased coverage of the issue indulging in moralizing, open prejudice, ridicule, etc. Stories that are full of jargon or stereotypical language, which lacks any sort of research, history or context and used discriminatory language for LGBT community ("the homosexuals, "the gays", etc.) are incorporated in this category. The stories which are constructive and incomplete are considered as 'not applicable'.

h. Number of photos used: This classification shows how many photos are employed in an article to provide a visual context to it. The published articles are classified on the basis of whether the article has one photograph, no photographs or more than one photograph.

i. Photo category: The photos are categorized on the basis of whether it represents lawmakers/government representatives, transgender, gays, lesbians, celebrities, and heterosexual people or whether the article did not have any image.

j. Threats portrayed in opposing viewpoints: In this study, the articles which poses homosexuality or homosexuals as the threats inflicted on any pertinent context are identified. Such threats are portrayed in the articles in the form of opposing viewpoints or negative statements on society, on marriage, family values, morals or any other issue (Sinkhorn, 2011). Those articles which are positive are classified as posing 'no threats'.

\section{Data analysis and discussion of findings}

The objective of quantitative analysis is to develop and employ mathematical models, theories and hypotheses pertaining to natural phenomena (Chandran, 2004). In this study, quantitative technique involved reducing text to numbers and 
then those numbers are counted, summed up and compared. Further, the qualitative technique is employed in the interpretation of the findings.

4.1 Type of story. The articles published in the newspapers are of different types that comprised news, editorials comments, cartoons, personal story, and photo story.

From Table 2, it can be comprehended that there are 90 news, 5 editorials, 151 comments, 3 cartoons, 25 personal stories, and 15 photo stories. Comments accounted for the highest number of published articles because it came from all corners of the intelligentsia including celebrities, political leaders, liberals, lawmakers and LGBTQ community itself who unequivocally welcomed it and shared their perception on its long-term effects on the Indian society. There are others who exhibited their joy and happiness after the verdict. As expected, all the national dailies gave a wide coverage of the verdict of the Supreme Court in form of news, which made it the second most published types of articles in the period of study. There are many personal stories of LGBTQ people and activists about the struggles faced by them before the decriminalization of Section 377 .

Table 2. Type of story

\begin{tabular}{lc}
\hline \multicolumn{1}{c}{ Type of story } & Number of articles \\
\hline News & 90 \\
Editorials & 5 \\
Comments & 151 \\
Cartoons & 3 \\
\hline Personal story & 25 \\
Photo story & 15 \\
\hline Total & $\mathbf{2 8 9}$ \\
\hline
\end{tabular}

4.2 Placement of story. News is classified according to its importance and relevance and category in which they lie. The placement of news does carry a significant impact and decides the weightage accorded to the issue in hand. It is therefore important as to where news is granted place in the newspaper.

From Table 3, it can be seen that thirty seven news stories got placed on the front page as it was groundbreaking verdict by the Supreme Court in favor of the LGBTQ community while thirty one stories are carried on the city page where the local citizens had something to speak about the nuances of the judgment. All the comments and reaction of politicians and the political parties on the verdict are assimilated on the political page that accounted for seventeen stories. Fifty-nine stories are on the nation page, which encompassed stories from around the nation. Editorial page is considered one of the most important pages as it enumerates the 
Table 3. Placement of story

\begin{tabular}{lc}
\hline Placement of story & Number of articles \\
\hline Front Page & 37 \\
\hline City Page & 31 \\
Politics Page & 17 \\
\hline Nation Page & 59 \\
Editorial Page & 34 \\
Business Page & 8 \\
Others & 103 \\
\hline
\end{tabular}

official stance of the newspaper on a given issue. There are thirty-four editorials published all together. Any incentives or anything related to business and employment in connection with LGBTQ community got place on the business page that accounted for eight stories. The highest number of stories is printed on 'other' pages. Such pages are mainly those that are exclusively dedicated to the verdict and carried comments and views of sections of society on the verdict. As many as 103 stories are printed on pages that are specifically dedicated to LGBTQ community indicating the prominence given to the news articles by in terms of accessibility and readership.

4.3 Size of the articles. The size of the articles is categorized in words. The news is always presented as crisp and informative. This implies that the word limits on any reporting do decide the weightage accorded to a given issue.

Table 4 shows that the highest number of stories have between $0-100$ words as it is mostly in the form of the comments of the celebrities, politicians, social activists and people of LGBTQ community who shared their views and opinions on the verdict. The photo stories and cartoons are also part of this classification. Therefore, 103 stories out of 289 stories fell in this category. From the findings, it is clear that small articles had the highest number of publications with 35.64 percentages. It is also observed that 43 stories have between 100-500 words, the lowest number of publications with 14.87 percentages, 49 stories have between 500-1000 words, and 65 out of 289 stories have more than 1000 words. The latter usually comprised personal stories, opinions and viewpoints of the intelligentsia and the specialists/

Table 4. Size of the article

\begin{tabular}{cc}
\hline Size of the articles (number of words) & Number of articles \\
\hline $0-100$ & 132 \\
$100-500$ & 43 \\
$500-1000$ & 49 \\
1000 above & 65 \\
\hline
\end{tabular}


activists. That the newspapers devoted so much space to the nuances of the verdict itself is a reflection of the importance accorded to this issue.

4.4 Types of Headlines. The research divided the headlines in four categories. Informative headlines provide brief information on what an article is about while the interpretative headlines present the personal points of view put forward by the author or editor. The interrogative headlines pose question to the readers that is made by the author or the editor and the headlines falling into none of the above categories are placed in 'others' category.

From Table 5, it is observed that thirty nine percentage of articles had an informative headline where it is clear what the story wanted to convey to the readers and are informative in nature whereas fifty one percentage that is more than half of the articles had an interpretative headline which partially told what the story is about but are left to the readers how they interpret it. Out of all the articles only three percent of them have an interrogative headline where the author posed a question about the validity of the story, whereas seven percentage of headlines had a different appeal as they did not lie in the above three categories.

Table 5. Types of headline

\begin{tabular}{cc}
\hline Types of headline & No. of articles \\
\hline Informative & 113 \\
Interpretative & 146 \\
Interrogative & 10 \\
\hline Other & 20 \\
\hline
\end{tabular}

4.5 Viewpoints. This is considered the themes of the articles. Themes are coded based on what Kuhar (2003) developed in his study, the five basis mechanisms of media representation of homosexuality: stereotyping, sexualization, secrecy and normalization medicalization and others.

Table 6 shows that 51 percent of the stories are in the category of secrecy and normalization. In this category, articles, which emphasize confidentiality of sexuality of homosexuals, are incorporated. On the other hand, it also features stories and viewpoints, which aims at highlighting normalized perception of homosexuality, which frames it as something ordinary. From the further research findings, it is seen that 19 percent of the viewpoints are about sexualization, which portrays homosexuality solely on basis of sexuality and sex. It is also seen from the study that sixteen percent have a stereotypical view regarding LGBTQ community, whereas six percent of the story have a viewpoint about medicalization. It is used to indicate that homosexuals need more medical examination to ascertain their problems. Some articles have a different viewpoint that did not fit in any of the above-men- 
Table 6. Viewpoint

\begin{tabular}{lc}
\hline \multicolumn{1}{c}{ Viewpoints } & Number of articles \\
\hline Stereotyping & 45 \\
Sexualization & 55 \\
Secrecy and normalization & 148 \\
Medicalization & 17 \\
Others & 24 \\
\hline \multicolumn{1}{c}{$\quad$ Total } & $\mathbf{2 8 9}$ \\
\hline
\end{tabular}

tioned categories that comprise eight percent of the total articles published. Most of them are photo stories and cartoons whose viewpoints are unclear.

4.6 Use of frame on homosexuality. The analysis of articles published in the national dailies revealed a framework to perceive issues pertaining to homosexuality. Such frameworks are broadly categorized for all the published articles as follows:

From Table 7, it can be seen that thirty seven percent of the articles talk about the equality and fundamental rights of all the citizens of the nation. They articulate about freedom of denizens to choose their sexual orientation and live freely, whereas twenty four percent are focused on the identity of LGBTQ community advocating that they have their own identity and that should be respected. Morality framework is used in twenty percent of the articles that spoke about the moral values. From the study, it is also found out that nineteen percent of the articles have a different framework other than equality, morality and identity.

Table 7. Use of frame on homosexuality

\begin{tabular}{|c|c|}
\hline Use of frame on homosexuality & Number of articles \\
\hline Equality & 108 \\
\hline Morality & 57 \\
\hline Identity & 70 \\
\hline Other & 54 \\
\hline Total & 289 \\
\hline
\end{tabular}

4.7 Stance on homosexuality. In our study, the published articles are classified as having positive, negative or neutral stance on issues concerning LGBTQ community.

In the study, eighty six percent of the articles have a positive stance on homosexuals, homosexuality and the verdict. This unequivocally demonstrates that people welcome the verdict and are in favor of it. Only six percent of the articles have a negative stance as some political and religious leaders are not in favor of the 
Table 8. Stance on homosexuality

\begin{tabular}{|c|c|}
\hline Stance on homosexuality & Number of articles \\
\hline Negative & 16 \\
\hline Positive & 249 \\
\hline Neutral & 24 \\
\hline Total & 289 \\
\hline
\end{tabular}

verdict as they treat it with the lens of religion and religious morality and condemn it as mental illness and hold it as a disparaging influence on the family values and cultural norms of the society. Some articles adopted a neutral stance on the abovementioned issues. They argue that since the top court has already pronounced its verdict on the issue, the decision has to be respected and abided. This shows that homosexuals and homosexuality are finding acceptance in the Indian society, which is reflected in the positive views and comments of the intelligentsia and the common people thus integrating LGBTQ community in social mainstream wholeheartedly.

4.8 Standpoint/ treatment of story. Each article published in the newspaper carry with it an integral standpoint on the issues facing the LGBTQ community. This is particularly manifested in editorials, comments, and personal stories.

From the research findings, it is observed that five percent of the articles standpoint and treatment are on religion and homosexuality where they are labelled as against the prevalent religious and cultural values. On the other hand, thirty eight percent of the articles treat homosexuality and its association with rule of law. Further, it observed that thirty six percent of the articles associated homosexuality with social stigma prevalent in the society. Homosexuality has always been perceived as a negative trait in India and is condemned as a by-product of western culture and influence. Still only five percent of the articles are classified as implying homosexuality as western influence. People do face discrimination at workplace and so do homosexuals. It is witnessed from the research that five percent of the

Table 9. Standpoint/ treatment of story

\begin{tabular}{lc}
\hline \multicolumn{1}{c}{ Standpoint/ treatment of story } & Number of articles \\
\hline Religion and homosexuality & 14 \\
Homosexuality and Rule of law & 109 \\
Homosexuality leads and social stigma & 105 \\
Homosexuality as a western influence & 15 \\
Homosexuality and discrimination at workplace & 12 \\
Others & 34 \\
\hline \multicolumn{2}{c}{ Total } \\
\hline
\end{tabular}


articles have a standpoint that highlights discrimination faced by homosexuals at workplace. There are certain articles, which did not fall in any of the above-mentioned categories are classified as 'others'. Such stories are accounted to be twelve percent of the total articles published.

4.9 Qualitative framework of the article. Articles that are published after the verdict on homosexuality are further classified based on qualitative framework. They are categorized as constructive, incomplete, negative and others.

Table 10 demonstrates that seventy eight percent of the articles are constructive in nature which is decided by the categories mentioned in Table 10.On the other hand it can also be seen that only six percent of the articles are incomplete that are subsequently sub-categorized in Table 11 whereas nine percent of the articles accounted to be negative in nature which are decided by the classification mentioned in Table 12.

Table 10. Qualitative framework of the article

\begin{tabular}{lc}
\hline Qualitative framework of the article & Number of articles \\
\hline Constructive stories & 224 \\
Incomplete stories & 17 \\
Negative stories & 27 \\
Others & 21 \\
\hline \multicolumn{2}{c}{ Total } \\
\hline
\end{tabular}

4.10 Classification of constructive stories. The articles are further classified based on the qualitative approach towards the article and the categories are decided accordingly. The constructiveness is decided whether it has the voices of the LGBTQ people, fairness in approach and so on.

From the study it is inferred that twenty seven percent of the articles recognize the voices of LGBTQ people on various issues faced by the community. Majority of the articles ( 50 percent to be precise) published during the period of the study has fairness of approach towards LGBTQ community. Some articles provide deep

Table 11. Classification of Constructive stories

\begin{tabular}{lc}
\hline \multicolumn{1}{c}{ Classification of Constructive stories } & Number of articles \\
\hline Voices of LGBT people & 62 \\
Fairness in approach to issue: no open prejudice, no ridicule, no moralizing & 115 \\
Provides research, history and context & 29 \\
Inclusive language to refer to LGBTQ people & 23 \\
Others & 2 \\
\hline Total & $\mathbf{2 3 1}$ \\
\hline
\end{tabular}


insight by way of employing research and digging historical perspective on the struggles of LGBTQ community. Further ten percent of the published articles employ explicit inclusive language for the said community.

4.11 Classification of incomplete stories. Certain attributes are assigned to articles, which are deemed to be 'incomplete'. Such attributes are classified and study is carried out to ascertain number of articles possessing such characteristics.

Majority of such incomplete stories are written without carrying out adequate background research. Such stories comprise fifty three percent of the above-mentioned categories. More than a quarter of the stories belonging to this category are devoid of inclusive language for LGBTQ community. About seven percent of such incomplete stories fail to address the stereotypes pertaining to LGBTQ community. The same number of articles also fails to report unbiased coverage of the underlying issues. About six percent of the articles lack the voices of people belonging to LGBTQ community.

Table 12. Classification of Incomplete stories

\begin{tabular}{lc}
\hline \multicolumn{1}{c}{ Classification of Incomplete stories } & Number of articles \\
\hline Lack of voices of LGBTQ people & 1 \\
Fails to address stereotypes & 1 \\
Failure to address tendency for biased coverage or provide context & 1 \\
Lack of context & 0 \\
Lack of research, history context & 1 \\
Lack of inclusive language & 8 \\
Others & 4 \\
\hline \multicolumn{1}{c}{ Total } & 16 \\
\hline
\end{tabular}

4.12 Classification of negative stories:. Of all the negative stories published during the period of study, their classification is broadly done as follows:

Table 13. Classification of negative stories

\begin{tabular}{lc}
\hline Classification of negative stories & Number of articles \\
\hline Lack of voices of LGBTQ people & 4 \\
Perpetuates stereotypes & 8 \\
Biased coverage of the issue: moralizing, open prejudice, ridicule, etc. & 4 \\
Full of jargon or stereotypical, biased language & 2 \\
Lack of research, history, context & 2 \\
Discriminatory language ("the homosexuals", "gays", etc.) & 0 \\
\hline \multicolumn{1}{c}{ Total } & $\mathbf{2 0}$ \\
\hline
\end{tabular}


About forty percent of the total negative stories published perpetuate stereotypes associated with LGBTQ people. It is observed that twenty percent of the negative stories forward biased reports on certain issues facing homosexuals whereas the similar number of stories fails to provide voice to LGBTQ community. It is further inferred that ten percent of the negative stories lack adequate research on matters concerning homosexuals. The stories full of jargon constitute ten percent of the total articles.

4.13 Number of photos used. Photos provide visual context to a story and imparts relevance to the issue in hand.

Most of the articles published (sixty-two percent) carried a photo describing the intent of the story. Only eight percent of the articles carry more than one associated picture while thirty percent of the articles are devoid of any photo.

Table 14. Number of photos used

\begin{tabular}{|c|c|}
\hline Number of photos used & Number of articles \\
\hline None & 86 \\
\hline One & 179 \\
\hline More than one & 24 \\
\hline Total & 289 \\
\hline
\end{tabular}

4.14 Photo Category. The pictures/photographs carried in the story reflect its mood and intent.

Major chunk of the articles features trans-genders (nineteen percent), gays (twelve percent) or lesbians (six percent) in the photo category. Further, eighteen percent of the articles portrays celebrities who enumerate their opinion on the verdict. Comments and opinions are also elicited from the lawmakers who included judiciary, politicians and government representatives. Hence they account for sixteen percent of the total photos featured. Only one percent of the articles pertaining to the judgment carry a photo of heterosexuals.

Table 15. Photo Category

\begin{tabular}{lc}
\hline \multicolumn{1}{c}{ Photo Category } & Number of articles \\
\hline Lawmakers/government representatives & 45 \\
Transgender & 55 \\
Gay men & 34 \\
Lesbian & 18 \\
Celebrities & 53 \\
Heterosexual people & 2 \\
No images & 82 \\
\hline
\end{tabular}


4.15 Threats portrayed in opposing viewpoints. In the present study carried out to ascertain the judgement of the apex court, certain articles highlight the acceptance of LGBTQ community as a threat to the established norms of religion, society and prevailing culture. Majority of such articles fell into the category of negative or incomplete stories.

Table 16. Threats portrayed in opposing viewpoints

\begin{tabular}{|c|c|}
\hline Threats portrayed in opposing viewpoints & Number of articles \\
\hline Society & 8 \\
\hline Marriage & 3 \\
\hline Family Values & 0 \\
\hline Morals & 5 \\
\hline Others & 0 \\
\hline Total & 16 \\
\hline
\end{tabular}

Exactly half of such articles pose homosexuals as a threat to the society while thirty one percent of such articles view it as a threat to established norms and moralities. Some articles pose homosexuality as a threat to institution of marriage.

\section{Results}

The present studies are carried out to verify the veracity of stated hypotheses and objectives enumerated in Section 3.

\subsection{Realization of stated objectives}

\section{Objective (a)}

Thirty-seven percent of the articles talk about the equality and fundamental rights of all the citizens of the nation. They also advocate about right to choose one's sexual orientation and live freely. It is observed that eighty-six percent of the articles published in these newspapers carry a positive view about homosexuals and homosexuality. Only six percent of the articles have a negative stance and oppose the verdict of the apex court as detrimental to the cause of the nation and the society. Interestingly, more stories exhibit neutral stance on the subject than the number of negative news. Most of the articles discuss about homosexuality in light of the rule of law and support decriminalization of homosexuals and homosexuality. They also condemn the social stigma attached to LGBTQ community and support their claim of equality before the law and in the eyes of the society. Further about seventy eight percent of the articles published are constructive in nature imparting fairness in approach to concerns facing LGBTQ community. Majority of the articles lent voices to LGBTQ people and highlighted their miseries and discrimination in the past. Out of the 289 articles, published only 36 are deemed to be critical of the verdict. 
Conclusion: Prior to the verdict, the Indian media had consistently adopted a neutral stance on homosexuality and engaged in diplomatic coverage of the issue. This study amply proves that there has been a paradigm shift in media reporting about LGBTQ community after the verdict of the Supreme Court and points towards shifting position of the intelligentsia in the society regarding homosexuals and homosexuality.

\section{Objective (b)}

It is noted that the six newspapers selected for the content analysis published staggering 215 articles on the next day after the Supreme Court pronounced the verdict. Further, the majority of all the articles published are either in the form of personal comments or news. Some of these comments highlighted the views and analysis of the judiciary and the judicial experts who educated the readers about the nuances of the judgment. The comments are also elicited from media persons, civil right activists, LGBTQ activists, and celebrities who welcomed the judgment and deliberated about its positive impacts on the society. As much as 34 news items are published as editorials on the editorial page of the selected newspapers which demonstrate the weightage accorded by these national dailies to the said verdict. Most of the articles published are either on the front page (37) or on the nation page (59). In fact, many newspapers carried special pages dedicated exclusively to accommodate the views, news, and comments pertaining to this judgment. It is therefore not surprising to note that majority of the articles published (103) are in such "other pages." Many of such articles are allotted ample space which is indicted by the size of the articles published. As many as 114 articles are more than 500 words that found prominent placement in the newspaper. Due weightage is accorded to stories (51 percent) which are interpretative in nature and elaborated the impact and after-effects of the verdict on the society.

Conclusion: This conclusively proves that Indian newspapers deliberated on the content, rationale of the verdict and its impact on the Society. Further, it educates the readers on its merits and highlights its reformists approach along with the benefits accruing to the sexual minority community.

\section{Objective (c)}

Agenda-setting theory describes the ability of the news media to impact the importance placed on the themes of the public agenda. With agenda setting being a social science theory, it also attempts to make predictions. That is, if a news item is covered frequently and prominently, the audience will regard the issue as more important. By comparing the salience of issues in news content with the public's perceptions of the most important underlying issues, McCombs and Shaw (1972) were able to determine the degree to which the media determines public opinion.

By the qualitative and quantitative findings as stated in objective (b) it can be concluded that the print media has honed the responsibility to educate the masses 
about the merits and rationale of the apex court ruling on issues of decriminalization of homosexuality. This demonstrates that the media appears to have a reformist agenda in line with the judiciary to end discrimination against LGBTQ community perpetrated through archaic imperial laws. Further, by highlighting the struggles and sagas of the sexual minority in the nation, it has brought to forth the inherent discrimination facing LGBTQ community and the consequential economic loss to the society. Hence, it has lent support to the right to equality, freedom of speech and expression as enshrined in the Indian constitution. The national dailies have not only highlighted the issue, but also insinuated its readers about how to perceive homosexuality as a form of sexual freedom rather than an aberration.

Conclusion: This establishes unequivocally that the print media is successful not only in setting the agenda for its readers, but also helped in framing their mindset regarding LGBTQ community and issues relating to them thus lending strong credence to the Framing Theory. Since about eighty six percent of the articles published in these newspapers carried a positive view about homosexuals and homosexuality, the affective attribute of second level agenda setting of print media in framing stance on homosexuality is conclusively established.

\section{Objective (d)}

It is inferred from the present study that the perception of the society towards LGBTQ community has seen a radical shift in past few years. This is amply reflected in standpoint and treatment of stories published in the national dailies after the apex court delivered the judgment on the decriminalization of homosexuality. It was earlier perceived that all the major religions practiced in India are inherently opposed to homosexuality and consider it to be a sin. But only 14 of the 289 articles published have any religious connotation to the verdict. Before the verdict, it was falsely propagated by an influential section of the society that homosexuality is nothing but a disparaging effect of western culture on the Indian society. This is again not reflected in the number of articles, which equates homosexuals as a product of western influence. There are only 15 articles published that attempted to link both of them. In fact, some of the articles chronicled the struggles and reforms instituted in the western society on the issue of homosexuality. Most of the articles, which are in form of comments by the intelligentsia, denounced the social stigma attached to homosexuality and the repercussion and imbalance it causes to the Indian society. There are 105 such articles of this nature which found space in media coverage of the verdict.

Strangely enough, not much importance has been accorded to discrimination faced by LGBTQ community at various stages of employment both in government and in private sector. There were 12 such articles highlighting the plight of homosexuals in these matters and the consequential economic laws to the nation. Majority of the articles (109) welcomed the verdict and supported the change in the law, 
which removed the tag of a criminal attached to LGBTQ community. That majority of the articles published (224) are constructive in their approach and supported the rights of LGBTQ people amply vindicate the changing social paradigm of the Indian society towards homosexuals and homosexuality.

This research also brings forth the peculiar characteristics of the language used in these articles. In fact, there is ample evidence that language and pictures have a critical role in determining the soul, essence, and intent of the articles. In this context, it is pertinent to note that the term LGBTQ is used 1156 times in the published articles. Similarly, the word "gay" is used 583 times, "homosexuals" 434 times, "transgender" 296 times, "bisexuals" 293 times and "lesbians" 275 times. While this can be considered as natural selection of words, it highlights the acceptability of such words in common parlance. Further, about 37 percent of the photos used in the articles belonged to LGBTQ community, which also points at their acceptability in the society and lends credence to their growing identity of LGBTQ.

Conclusion: The above arguments show beyond doubt that reporting in the media on issues pertaining to LGBTQ community is a direct reflection of the changing attitude and social paradigm of the Indian society. They are no longer viewed as sinners or criminals but only as persons with alternative thinking and personal choices, which needs to be respected.

\subsection{Evaluation of Research Questions of the study}

With these established conclusions, the Research Questions posed in this study are addressed as follows:

Research Questions 1: Although taboos are an integral part of all the existing societies of the world, significant alterations are possible in them with right efforts where media, intelligentsia and leaders play a proactive role is dissemination of information which can lead to its gradual weakening and discarding by the majority section of the society. This study demonstrates that with a will power of the masses and reformist approach of the media, any existing social taboo can be challenged and jettisoned. Further, the social stigma attached to individuals or a minority group can be done away if synergetic efforts of intellectuals, leaders and media are put in place.

Research Questions 2: This study conclusively proves that the media has the power and effectiveness to instigate social change and reorient the opinion of the masses regarding such social groups like LGBTQ which do not conform to mainstream norms. It unequivocally demonstrates that media has the ability to set the agenda and alter the tenor of thinking of the society on vexed issues which had earlier received legal and religious sanction. Thus, the second level of agenda setting by the media can be utilized to renounce established prejudices and stereotypes prevailing in the society paving way for much needed social reform. 


\subsection{Comparison of the results with past studies}

The content analysis carried out by Mbugua (2010) established that in a politically conservative country like Kenya, the media tends to report what is politically correct and issues that conforms to the general public norm. Therefore, the media choose to portray homosexuality in a negative manner as this conforms to the general public idea or stereotype images of homosexuality. This study suggests that it would have been ideal if the media took greater responsibility for and placed more focus on generating unbiased reports. But in our study, it is conclusively proved that if the media proactively takes up the issue of sexual minorities like LGBTQ community in a reformist manner, it can alter the perception of the society towards such social groups which do not conform to mainstream norms.

The present study also takes into account the stance taken on LGBTQ issues by the selected national dailies. It does show that the majority of the articles published in the said period of study took equality stance and positive viewpoint conforming a shift in the media coverage of LGBTQ issues in India from 'diplomatic' to proactive and reformist. These bolters claim made in study carried out by Sinkhorn (2011) that stance taken by the media on LGBTQ issues does influence mass opinion. The present study conforms to finding of Calzo and Ward (2009) which concluded that increased media exposure had mainstreaming effect on audiences/ readers. Indeed, the positive media coverage of LGBTQ community and associated issues have ushered an era of Rainbow Nation ${ }^{5}$ in the Indian society where the barriers of discrimination against such minority groups has been significantly lowered. The study conducted by Raley and Lucas (2006) also concluded that media contributes to reduction in negative stereotypes of LGBTQ community which is also comprehensively established in the present study. The present study lends credence to conclusions reached in a study conducted by Chen (2018) that public images of the LGBTQ community have been differently depicted and reformed on the basis of mass media coverage.

\section{Limitations}

Although the content analysis is carried out scientifically and due research procedures are followed which ensures reliability of the results obtained, certain limitations of the study needs to be highlighted.

The primary limitation of the study is that the time frame of the said research is selected for a period of one week after the deliverance of Supreme Court verdict. Although this puts a constraint on the results obtained, the same cannot be entire-

5 https://www.macmillandictionary.com/us/dictionary/american/rainbow-nation. Accessed on November 2019. 
ly discarded. This time period saw a plethora of articles and news regarding issues concerning LGBTQ community which saw opinions of all spectrums from different sections of society. This is reflected in the huge number of articles published in selected newspapers which made it convenient for a rigorous scientific analysis.

The vernacular press is not included in the research which has resulted in the omission of certain newspapers with wide circulation in India. Although this might appear to pose a restraint which may affect the outcome of the study, it is worth mentioning that most of those vernacular newspapers belong to the same media publications as of the selected national dailies. Hence the opinions of all major media houses are duly incorporated in our study.

The code for qualitative analysis used in the present study is based on five basis mechanisms of media representation of homosexuality developed by Kuhar (2003). Although one can apply other coding procedures for similar studies, the same is selected for the present research as it is most widely prevalent coding system applied worldwide for the study of issues pertaining to LGBTQ community. It is suggested that any future endeavors can attempt to improve the research design, such as codebook design and the unit of analysis.

\section{References}

1. Abdulla, Raficq S., Mohamed M. Keshavjee (2018). Understanding Sharia: Islamic Law in a Globalized World. London, Oxford: Bloomsbury.

2. Article 21 in The Constitution Of India 1949 - Indian Kanoon. Retrieved from: https:// indiankanoon.org/doc/1199182/. Accessed on November 2019.

3. Avila-Saavedra, G. (2009). Nothing queer about queer television: televised construction of gay masculinities. Media, Culture \& Society, 31(1), 5-21. https://doi. org $/ 10.1177 / 0163443708098243$.

4. Balmas, M., \& Sheafer, T. (2010). Candidate Image in Election Campaigns: Attribute Agenda Setting, Affective Priming, and Voting Intentions. International fournal of Public Opinion Research, 22(2), 204-229. doi:10.1093/ijpor/edq009.

5. Bühler, Georg (1886). The laws of Manu. Oxford: Clarendon Press. Retrieved from: https://archive.org/details/lawsofmanu00bh. Accessed on November 2019.

6. Calzo, J.P., Ward, L.M. (2009). Media exposure and viewers' attitudes toward homosexuality: Evidence for mainstreaming or resonance? fournal of Broadcasting \& Electronic Media, 53, 280-299.

7. Chandran, E. (2004). Research methods: A quantitative approach with illustrations from Christian ministries. Nairobi, Kenya: Daystar University.

8. Chen,Y. A. (2018). Media Coverage and Social Changes: Examining Valence of Portrayal Of The LGBT Community from 2000 to 2014 in Two U.S. Magazines. Intercultural Communication Studies XXVII, University of Wisconsin-Madison, USA. Retrieved from https://web.uri.edu/iaics/files/Y.-Anthony-Chen.pdf. 
9. Choudhry, Sujit, Madhav Khosla, and Pratap Bhanu Mehta (ed.) (2016). Writs and Remedies. The Oxford Handbook of the Indian Constitution. Retrieved from: https:// www.oxfordhandbooks.com/view/10.1093/law/9780198704898.001.0001/oxfordhb9780198704898-e-34 Accessed on November 19, 2019.

10. Cook, C. (2018). A Content Analysis of LGBT Representation on Broadcast And Streaming Television (Honors Thesis, University of Tennessee, USA) Retrieved from: https:// pdfs.semanticscholar.org/3496/5eb35b8b8c648f00210bbcd5f1984cbf08b6.pdf. Accessed on November 2019.

11. Croome, Rodney (n.d.). Churning the mud. Griffith Review. Retrieved, from: https://test. griffithreview.com/articles/churning-the-mud/. Accessed on November 19, 2019.

12. Dave, Naisargi N. (2010). To Render Real the Imagined: An Ethnographic History of Lesbian Community in India. Fournal of Women in Culture and Society, 35(3).

13. David, K., \& Pavlik, V. J. (2003). Agenda Setting and Media coverage of SARS. International Agenda Setting Conference, Bonn, Germany.

14. Entman, R. M. (1993). Framing: Toward clarification of a fractured paradigm. fournal of Communication, 43(4).

15. European Union Agency for Fundamental Rights. (2009). Homophobia and Discrimination on Grounds of Sexual Orientation and Gender Identity in the EU Member States Part II - The Social Situation. doi: 10.2811/13477. Retrieved from: https://fra.europa.eu/sites/default/ files/fra_uploads/397-FRA_hdgso_report_part2_en.pdf Accessed on November 2019.

16. General Assembly resolution 2200A (XXI), International Covenant on Civil and Political Rights (16 December 1966), Retrieved from https://www.ohchr.org/en/professionalinterest/pages/ccpr.aspx. Accessed on November 2019.

17. Ghanem, S. (1997). Filling in the Tapestry: The Second Level of Agenda Setting. In M. McCombs, D. Shaw \& D. Weaver (Eds.), Communication and Democracy: Exploring the Intellectual Frontiers in Agenda-Setting Theory. (pp. 3-14). Hillsdale, New Jersey: Lawrence Erlbaum Associates.

18. Humsafar Trust (n.d.). Retrieved from: https://humsafar.org/. Accessed November 19, 2019.

19. Ivory, A. H., Gibson, R., \& Ivory, J.D. (2009). Gendered Relationships on Television: Portrayals of Same-Sex and Heterosexual Couples. Mass Communication and Society, 12(2), 170-192.

20. Jawale, K. V. (2016). Issues and challenges of 'LGBT' minority people in India. International Journal of Applied Research, 2(6), 408-410.

21. Kuhar, R. (2003). Media Representation of Homosexuality. An Analysis of the Print Media in Slovenia, 1970-2000, Peace Institute. Retrieved from: http://mediawatch.mirovniinstitut.si/eng/media_representations_of_homosexuality.pdf. Accessed on November 2019.

22. Law Commission of India. (1971). Indian Penal Code (Report No. 42). Ministry of Law, Government of India. Retrieved from: http://lawcommissionofindia.nic.in/1-50/Rep ort42.pdf. Accessed on November 2019. 
23. Lewis, William (1990). Neither Man nor Woman - the Hijras of India. Book Review. SAGE Journals. https://doi.org/10.1177/016059769001400314.

24. Mbugua, N. S. (2010). Mass Media Framing Of Homosexuality: A Content Analysis of the National Daily Newspapers In Kenya (Master's thesis, School Of Journalism And Mass Communication, University Of Nairobi, Kenya) Retrieved from http://erepository. uonbi.ac.ke/bitstream/handle/11295/3412/Abstract.pdf?sequence=1. Accessed on November 2019.

25. McCombs, M. \& Evatt, D. (1995). Los temas y los aspectos: Explorando una nueva dimension de la agenda setting. [Objects and Attributes: Exploring a New Dimension of Agenda Setting] Comunicacion y Sociedad, 8(1), 7-32.

26. Mccombs, M. E., \& Shaw, D. L. (1972). The Agenda-Setting Function of Mass Media. Public Opinion Quarterly, 36(2), 176. doi: 10.1086/267990.

27. Mccombs, M., Llamas, J. P., Lopez-Escobar, E., \& Rey, F. (1997). Candidate Images in Spanish Elections: Second-Level Agenda-Setting Effects. Journalism \& Mass Communication Quarterly, 74(4), 703-717. doi: 10.1177/107769909707400404.

28. Nachmias, C., \& Guerrero, A. (2019). Social Statistics for a Diverse Society. SAGE Publications. Retrieved from http://us.sagepub.com/en-us/nam/social-statistics-for-a-diversesociety/book249326. Accessed on November 2019.

29. People's Union for Civil Liberties (PUCL) (n.d.). Retrieved from: http://www.pucl.org/. Accessed on November 2019.

30. Price, V., \& Tewksbury, D. (1997). News values and public opinion: A theoretical account of media priming and framing. In G. Barnett \& F. Boster (Eds.), Progress in communication sciences. (pp. 173-212). Norwood, N.J: Ablex Pub. Corp.

31. Raley, A. B. \& Lucas, L. J. (2006). Stereotype or success? Prime-time television's portrayals of gay male, lesbian, and bisexual characters. fournal of Homosexuality, 51(2), 19-38.

32. Schastneva, N. (2016). Representation Of LGBT Issues In Russian Mainstream News Media (Master's thesis, Russian Federation School of Humanities, Education and Social Sciences, Örebro University, Sweden). Retrieved from http://urn.kb.se/resolve?urn=urn:nb n:se:oru:diva-50893. Accessed on November 2019.

33. Scheufele, D. (1999). Framing as a Theory of Media Effects. Fournal of Communication, 49(1), 103-122. https://doi.org/10.1111/j.1460-2466.1999.tb02784.x.

34. Scheufele, D. (2000). Agenda-setting, priming, and framing revisited: Another look at cognitive effects of political communication. Mass Communication \& Society, 3(2), 297-316.

35. Section 377 in the Indian Penal Code - Indian Kanoon. Retrieved from: https://indianka noon.org/doc/1836974/. Accessed on November 2019.

36. Sen Gupta, I. (2005). Human Rights of Minority and Women's: Human rights and sexual minorities. Gyan Publishing House, India.

37. Sinkhorn, S. (2011). Newspaper Use Of Fear Appeal In Coverage Of LGBT Issues (Master's thesis, Ball State University Muncie, Indiana, USA). Retrieved from http://cardinalscholar.bsu.edu/bitstream/handle/123456789/195036/SinkhornS_2011-3_BODY. pdf?sequence=1\&isAllowed=y. Accessed on November 2019. 
38. Smith, C. (2005). Epistemological intimacy: A move to autoethnography. International Journal of Qualitative Methods, 4(2).

39. Stacks, D., \& Hocking, F. (1999). Communication research (2nd ed.) New York, Longman Publishers.

40. Supreme Court's verdict on Section 377 on September 6, 2018. Retrieved from: https:// www.thehindu.com/news/resources/full-text-of-supreme-courts-verdict-on-section377-on-september-6-2018/article24880713.ece. Accessed on November 2019.

41. Tabangcura, D.F. (2011). Media Representations Of Gay And Lesbian Couples With Families: A Multimodal Discourse Analysis of Proposition 8 Advertisements (Master's thesis, University of Colorado, USA). Retrieved from https://pdfs.semanticscholar.org/d9ae/9c 4b09f1f97d87065ce2ba72995594bdcb36.pdf. Accessed on November 2019.

42. The Constitution of the Republic of South Africa (1996). Department of Justice. Retrieved from: http://www.justice.gov.za/legislation/constitution/SAConstitution-webeng.pdf. Accessed November 19, 2019.

43. Weaver, D. H. (2007). Thoughts on Agenda Setting, Framing, and Priming. Fournal of Communication, 57, 142-147.

44. Yan, H. Y. (2019). “The Rippled Perceptions”: The Effects of LGBT-Inclusive TV on Own Attitudes and Perceived Attitudes of Peers toward Lesbians and Gays. Fournalism \& Mass Communication Quarterly, 96(3), 848-871. doi:10.1177/1077699018821327.

45. https://www.macmillandictionary.com/us/dictionary/american/rainbow-nation. Accessed on November 2019. 